\title{
PENGARUH MODEL PEMBELAJARAN ROLE PLAYING BERORIENTASI TRI KAYA PARISUDHA TERHADAP HASIL BELAJAR IPS KELAS IV
}

\author{
Ni Nyoman Tri Astrini ${ }^{1}$, Made Sumantri ${ }^{2}$, Ni Wayan Rati ${ }^{3}$ \\ Prodi Pendidikan Dasar, Universitas Pendidikan Ganesha, Singaraja \\ e_mail: nyoman.tri.astrini@undiksha.ac.id ${ }^{1}$, made.sumantri@undiksha.ac.id², niwayan.rati@undiksha.ac.id ${ }^{3}$
}

\begin{abstract}
Abstrak
Parisudha terhadap hasil belajar IPS. Penelitian ini merupakan penelitian quasi experiment dengan desain nonequivalent post-test only control group. Jumlah populasi dalam penelitian ini adalah 133 orang dan sampel penelitian berjumlah 43 orang yang diambil dengan teknik group desain random sampling. data hasil belajar IPS dikumpulkan menggunakan tes pilihan ganda. Data dianalisis dengan teknik analisis statistik deskriptif dan analisis statistik inferensial (uji-t). Hasil penelitian menunjukkan bahwa terdapat perbedaan hasil belajar antara siswa yang mengikuti model pembelajaran Role Playing Berorientasi Tri Kaya Parisudha dengan siswa yang mengikuti pembelajaran konvensional (sig 0,000<0,05), dengan demikian model pembelajaran Role Playing Berorientasi Tri Kaya Parisudha berpengaruh positif terhadap hasil belajar IPS siswa. Kata kunci : Hasil Belajar IPS, Role Playing Berorientasi Tri Kaya parisudha
\end{abstract}

\section{Abstract}

This study aims to determine the effect of the Tri Kaya-Oriented Learning Role Playing model on social studies learning outcomes. This research is a quasi-experimental study with a nonequivalent post-test only control group design. The population in this study was 133 people and the study sample was 43 people taken by group random sampling design technique. Social studies learning outcomes data were collected using multiple choice tests. Data were analyzed by descriptive statistical analysis techniques and inferential statistical analysis (t-test). The results showed that there were differences in learning outcomes between students who followed the Tri Rich Parisudha Oriented Role Playing learning model with students who took conventional learning (sig $0,000<0,05$ ), thus the Tri Kaya Parisudha oriented Role Playing learning model had a positive effect on learning outcomes Student social studies.

Keywords: Learning outcomes IPS, Tri Kaya Parisudha Oriented Role Playing

\section{Pendahuluan}

Sekolah Dasar (SD) sebagai titik awal pendidikan formal di Indonesia memiliki peran besar sebagai pondasi pengetahuan untuk jenjang pendidikan ke jenjang yang lebih tinggi. Sudah seharusnya Sekolah Dasar (SD) dapat memberikan pondasi yang kokoh bagi siswanya.Pendidikan di jenjang sekolah dasar telah dirancang beberapa mata pelajaran yang wajib diberikan kepada siswa, salah satunya yaitu mata pelajaran IImu Pengetahuan Sosial (IPS). Pembelajaran IPS merupakan serangkaian kegiatan yang melibatkan guru, siswa, dan bahan ajar IPS dalam rangka mencapai perubahan yang relatif tetap dalam pengetahuan, pemahaman, sikap, tingkah laku, dan keterampilan.

Dalam suatu pembelajaran di tingkat sekolah dasar siswa diajarkan beberapa mata pelajaran, salah satu mata pelajaran yang diajarkan yaitu IImu Pengetahuan Sosial (IPS). IImu Pengetahuan Sosial di sekolah dasar merupakan suatu dasar pengetahuan tentang cara-cara bermasyarakat, berinteraksi dengan orang lain karena manusia sebagai makhluk sosial tidak dapat hidup sendiri dalam arti lain manusia membutuhkan orang lain untuk hidup (makhluk sosial).

Hanafy (2014) menyatakan bahwa "belajar dan pembelajaran merupakan aktivitas terencana untuk mencapai tujuan tertentu yang dicirikan dengan keterlibatan sejumlah komponen yang saling terkait". Komponen-komponen dalam belajar dan pembelajaran yang dimaksud adalah perangkat pembelajaran yang terdiri atas rencana pelaksanaan pembelajaran, alat pembelajran yang mencakup metode, media, dan sumber belajar, serta alat evaluasi, baik dengan tes maupun nontes. Dalam kegiatan pembelajaran di sekolah, tugas utama seorang guru adalah mengajar, 
sedangkan tugas utama seorang siswa adalah belajar. Pembelajaran (instruction) merupakan akumulasi dari konsep mengajar (teaching) dan konsep belajar (learning).

IImu Pengetahuan Sosial (IPS) merupakan salah satu mata pelajaran yang diberikan kepada siswa sekolah dasar. Trianto (2010:171-172), "IPS merupakan integrasi dari berbagai ilmu-ilmu sosial seperti, sosiologi, sejarah, geografi, politik, hukum, dan budaya atas dasar realitas dan fenomena sosial yang terjadi di masyarakat". Melalui ilmu pengetahuan sosial siswa mampu mengamati, merasakan, berkomunikasi serta berinteraksi sebagai mahluk sosial dalam kehidupan sehari-hari. Selain itu Susanto (2014:138) berpendapat bahwa "Hakikat IPS adalah untuk mengembangkan konsep pemikiran yang berdasarkan realita kondisi sosial budaya yang ada dilingkungan siswa, sehingga dengan memberikan pendidikan IPS diharapkan dapat melahirkan warga Negara yang baik dan bertanggung jawab terhadap bangsa dan negaranya".

pada kehidupan nyata pembelajaran IPS di sekolah kurang menekankan pengembangan pemahaman dan sikap positif siswa terhadap nilai, norma dan moral yang berlaku dalam masyarakat serta terbatasnya kesempatan siswa untuk mengembangkan kompetensi-kompetensi yang dimilikinya.

Berdasarkan hasil wawancara dan observasi di SD Gugus VII Kecamatan Sukasada Kabupaten Buleleng pada tanggal 09 Januari 2019, bahwa dalam proses pembelajaran guru masih cenderung menggunakan metode ceramah, belum memaksimalkan model-model pembelajaran yang inovatif, Interaksi siswa masih rendah, hal ini ditandai jarang terlihat siswa mengajukan pertanyaan, siswa hanya menunggu informasi dari guru, guru hanya menyampaikan materi tanpa mengaitkan dengan nilai, norma dan moral yang berlaku dalam masyarakat Sehingga pembelajaran di kelas hanya terjadi satu arah, hal tersebut yang mengakibatkan rendahnya hasil belajar IPS siswa kelas IV di SD Gugus VII Kecamatan Sukasada Kabupaten Buleleng .

Hasil belajar IPS yang belum mencapai KKM, tentu akan berimbas pada keberhasilan mata pelajaran IPS di setiap sekolah. KKM adalah kriteria ketuntasan minimal yang dimiliki oleh masingmasing mata pelajaran dan ditentukan oleh masing-masing sekolah. Berdasarkan hasil studi dokumen nilai rata-rata hasil belajar IPS dari siswa kelas IV semester I di SD Gugus VII Kecamatan Sukasada Kabupaten Buleleng Tahun pelajaran 2018/2019 dapat dilihat pada Tabel 01 berikut:

Tabel 01 Rata-rata nilai UAS IPS Kelas IV

\begin{tabular}{ccccccc}
\hline No. & Nama Sekolah & $\begin{array}{c}\text { Jumlah } \\
\text { Siswa }\end{array}$ & $\begin{array}{c}\text { KKM } \\
\text { Sekolah }\end{array}$ & & $\begin{array}{c}\text { Jumlah Siswa yang } \\
\text { Mencapai KKM }\end{array}$ & Rata-rata Nilai \\
& & 26 & 70 & 11 & 15 & 70,38 \\
\hline 1 & SD Negeri 1 Selat & & Tuntas & $\begin{array}{c}\text { Tidak } \\
\text { Tuntas }\end{array}$ & \\
\hline 2 & SD Negeri 2 Selat & 31 & 60 & 14 & 17 & 59,67 \\
\hline 3 & SD Negeri 3 Selat & 23 & 75 & 7 & 16 & 50,43 \\
\hline 4 & SD Negeri 4 Selat & 20 & 70 & 10 & 10 & 72,75 \\
\hline 5 & SD Negeri 5 Selat & 23 & 60 & 12 & 11 & 75,86 \\
\hline 6 & SD Negeri 6 Selat & 10 & 70 & 3 & 7 & 56 \\
\hline
\end{tabular}

Dengan melihat hasil studi dokumen berupa daftar nilai ulangan umum di SD Gugus VII Kecamatan Sukasada Kabupaten Buleleng bahwa hasil belajar IPS siswa kelas IV masih belum mencapai KKM, maka diupayakan solusi dalam pelaksanaan pembelajaran yang lebih inovatif untuk meningkatkan hasil belajar siswa. Rusman, (2015:67) hasil belajar adalah "kemampuan yang dimiliki siswa setelah ia menerima pengalaman belajarnya". Hasil belajar pada konteks ini lebih mengarah pada pembelajaran IPS sangat erat kaitannya dengan belajar atau proses belajar dan hasil belajar siswa. Maka diupayakan solusi dalam pelaksanaan pembelajaran yang lebih inovatif untuk meningkatkan hasil belajar siswa. Salah satu upaya untuk mencapai keberhasilan dalam proses pembelajaran adalah menerapkan model pembelajaran yang sesuai dengan tahap perkembangan dan karakter siswa. salah satu model pembelajaran yang dapat meningkatkan hasil belajar siswa adalah Model pembelajaran Role Playing. Yuliani (2017) menyatakan Role playing (bermain peran) adalah sejenis permainan gerak yang di dalamnya ada tujuan, aturan dan 
sekaligus melibatkan unsur senang. Dalam role playing, siswa dikondisikan pada situasi tertentu di luar kelas, meskipun saat itu pembelajaran terjadi di dalam kelas.

Selain itu role playing seringkali dimaksudkan sebagai suatu bentuk aktivitas dimana anak didik membayangkan dirinya seolah-olah berada di luar kelas dan memainkan peran orang, role playing juga berfungsi sebagai penanam karakter kata atau penggunaan ungkapan. Selain itu model ini akan melatih siswa agar mereka mampu menyelesaikan masalah-masalah sosial psikologis serta dapat melatih siswa agar mereka dapat bergaul dan memberi kemungkinan bagi pemahaman terhadap orang lain berserta masalahnya (Kurniasih dan Sani, 2015:68). Sejalan dengan itu Fogg (dalam Huda, 2014: 208), "role playing atau bermain peran adalah sejenis permain gerak yang di dalamnya ada tujuan, aturan, dan edutainment". Kegiatan role playing menjadikan suatu pembelajaran yang menyenangkan, karena didesain dengan memadukan antarmuatan pendidikan dan hiburan secara harmonis. Pendapat tersebut sejalan dengan Khaerani (2010: 15) yang menyatakan bahwa: role playing membuat siswa menjadi lebih tertarik dan terlibat tidak hanya belajar mengenai suatu konsep, tetapi juga mengintegrasikan pengetahuan terhadap perilaku melalui pengklasifikasian masalah-masalah, mengeksplorasi alternatif-alternatif, dan mencari solusi-solusi yang kreatif.

Keunggulan model pembelajaran role playing Huda (2014:210) diantaranya adalah (1) dapat memberikan kesan pembelajaran yang kuat dan tahan lama dalam ingatan siswa, (2) bisa menjadi pengalaman belajar menyenangkan yang sulit untuk dilupakan, (3) membuat suasana kelas menjadi lebih dinamis dan antusias, (4) membangkitkan gairah dan semangat optimisme dalam diri siswa serta menumbuhkan rasa kebersamaan, (5) membuat siswa untuk terjun langsung memerankan sesuatu yang akan dibahas dalam preses belajar.

Berkaitan dengan model pembelajaran Role Playing, ada suatu konsep yang mengakar pada kehidupan sosial masyarakat Bali, yang dikenal dengan nama konsep Tri Kaya Parisudha. Tri Kaya Parisudha artinya tiga berbuatan manusia berupa pikiran, perkataan, dan prilaku yang harus disucikan (Suhardana, 2007: 25). Tri Kaya Parisudha merupakan suatu ajaran yang menjadi tuntunan bagi umat hindu di Bali yaitu tuntunan dalam berpikir, berkata, dan berbuat. Menyatunya aspek berpikir, berkata, dan berbuat merupakan kesatuan yang utuh dalam berperilaku atau berbuat dalam bermasyarakat. Tri Kaya Parisudha merupakan bagian dari etika (susila) agama hindu. Tri berarti tiga, Kaya artinya perbuatan atau gerak, Parisudha artinya suci atau baik dan benar. Dengan demikian, Tri Kaya Parisudha artinya tiga perbuatan yang harus disucikan. Tri Kaya Parisudha mempunyai tiga bagian yaitu: Manacika Parisudha (pikiran yang benar), Wacika Parisudha (perkataan yang benar), Kayika Parisudha (perbuatan atau laksana yang benar). Penerapan model pembelajaran Role Playing tentunya sangat baik digunakan dalam pembelajaran IPS karena dapat memaksimalkan pemahaman siswa sebagai makhluk individu maupun sebagai makhluk sosial. Maka dari itu, dalam proses pembelajaran model pembelajaran Role playing juga harus dipadukan dengan Tri Kaya Parisudha. Tri Kaya Parisudha merupakan suatu ajaran yang menjadi tuntunan bagi umat hindu di Bali yaitu tuntunan dalam berpikir, berkata, dan berbuat. Menyatunya aspek berpikir, berkata, dan berbuat merupakan satu kesatuan yang utuh dalam berprilaku atau berbuat dalam bermasyarakat. Penekanan konsep tersebut dalam pembelajaran IPS akan sangat membantu siswa untuk mengembangkan pengetahuan, pemahaman, dan keterampilan untuk menyelesaiakan masalah sosial yang terjadi dikehidupan siswa, sesuai dengan kemampuan belajarnya. Dengan demikian, ada hubungan antara model pembelajaran Role playing dengan konsep Tri Kaya Parisudha.

Berdasarkan uraian yang telah dipaparkan di atas, untuk mengetahui seberapa jauh perbedaan hasil belajar IPS siswa antara model pembelajaran Role Playing berorientasi Tri Kaya Parisudha dengan model pembelajaran konvensional, perlu dilakukan penelitian dengan judul "Pengaruh Model Pembelajaran Role Playing Berorientasi Tri Kaya Parisudha Terhadap Hasil Belajar IPS Siswa Kelas IV SD Gugus VII Kecamatan Sukasada 2018/2019”.

\section{Metode}

Penelitian ini menggunakan rancangan eksperimen semu (quasi eksperiment) dengan nonequivalent posttest only control group design. (dimodifikasi dari Sugiyono, 2012) Rancangan ini dipilih karena peneliti tidak mungkin mengubah kelas yang sudah ada atau sudah terbentuk. Desain penelitian ini yang secara prosedural dapat ditunjukkan dalam Tabel 02 berikut. 
Tabel 02 Rancangan Penelitian

\begin{tabular}{|l|l|l|}
\hline Kelas & Perlakuan & Post-test \\
\hline Eksperimen & $\mathrm{X}$ & $\mathrm{O}_{1}$ \\
\hline Kontrol & - & $\mathrm{O}_{2}$ \\
\hline
\end{tabular}

(dimodifikasi dari Sugiyono, 2012)

Penelitian ini merupakan penelitian eksperimen karena mengungkapkan hubungan sebab dan akibat dengan cara melibatkan kelompok kontrol dan kelompok eksperimen. Pada penelitian yang akan dilakukan tidak memungkinkan untuk mengadakan kontrol/manipulasi terhadap semua variabel yang relevan. Oleh karena itu penelitian ini termasuk penelitian eksperimen semu (quasi experiment).Penelitian ini menggunakan rancangan eksperimen semu (quasi eksperiment) dengan non-equivalent posttest only control group design. (dimodifikasi dari Sugiyono, 2012) Rancangan ini dipilih karena peneliti tidak mungkin mengubah kelas yang sudah ada atau sudah terbentuk. Desain penelitian ini yang secara prosedural dapat ditunjukkan dalam Tabel 03 berikut.

Tabel 03 Rancangan Penelitian

\begin{tabular}{|l|l|l|}
\hline Kelas & Perlakuan & Post-test \\
\hline Eksperimen & $\mathrm{X}$ & $\mathrm{O}_{1}$ \\
\hline Kontrol & - & $\mathrm{O}_{2}$ \\
\hline
\end{tabular}

(dimodifikasi dari Sugiyono, 2012)

Populasi dalam penelitian ini adalah seluruh siswa kelas V di Gugus IV Kecamatan Banjar Kabupaten Buleleng yang berjumlah 133 orang Sampel dalam penelitian ini ditentukan dengan teknik group random sampling. Berdasarkan hasil pengundian untuk menentukan kelas eksperimen dan kontrol, diperoleh sampel yaitu siswa kelas IV SD N 3 Selat sebagai kelas eksperimen dan siswa SD N 4 Selat sebagai kelas kontrol. Kelas eksperimen diberikan perlakuan pembelajaran dengan model Role Playing Berorientasi Tri Kaya Parisudha dan kelas kontrol diberikan perlakuan pembelajaran dengan model pembelajaran konvesional. Penelitian ini melibatkan dua variabel yaitu variabel bebas dan variabel terikat.

Variabel Bebas dalam penelitian ini adalah Role Playing Berorientasi Tri Kaya Parisudha sedangkan variabel terikatnya adalah Hasil Belajar IPS. Teknik pengumpulan data dalam penelitian ini adalah menggunakan tes. Teknik analisis data yang digunakan adalah statistik deskriptif dan statistik inferensial melalui Uji-t.

\section{Hasil dan Pembahasan}

Berdasarkan uraian mengenai hasil post-test IPS siswa pada kelompok eksperimen dan kelompok kontrol, terlihat adanya perbedaan hasil belajar IPS antara kelompok eksperimen (kelompok siswa yang dibelajarkan dengan menggunakan model pembelajaran Role Playing Berorientasi Tri Kaya Parisudha dan kelompok kontrol (kelompok siswa yang dibelajarkan dengan menggunakan model konvensional). Rangkuman hasil analisis statistik deskriptif disajikan pada Tabel

Tabel 04 Statistik Deskriptif

\begin{tabular}{lcc}
\hline \multicolumn{1}{c}{ Statistik } & Kelompok Eksperimen & Kelompok Kontrol \\
\hline Banyak Sampel & 23 & 20 \\
\hline Mean & 27,17 & 21,1 \\
\hline Median & 27 & 21 \\
\hline Modus & 27 & 21 \\
\hline Varians & 2,04 & 3,2 \\
\hline
\end{tabular}




\begin{tabular}{lcc}
\hline Standar Deviasi & 1,43 & 1,79 \\
\hline Skor Maksimum & 30 & 24 \\
\hline Skor Minimum & 25 & 17 \\
\hline
\end{tabular}

Berdasarkan Tabel 04. Diketahui bahwa mean data hasil belajar siswa kelompok eksperimen $=27,17$ lebih besar daripada kelompok kontrol $=21,1$ Kemudian data hasil belajar siswa kelompok eksperimen tersebut dapat disajikan ke dalam bentuk Histogram seperti Gambar 1

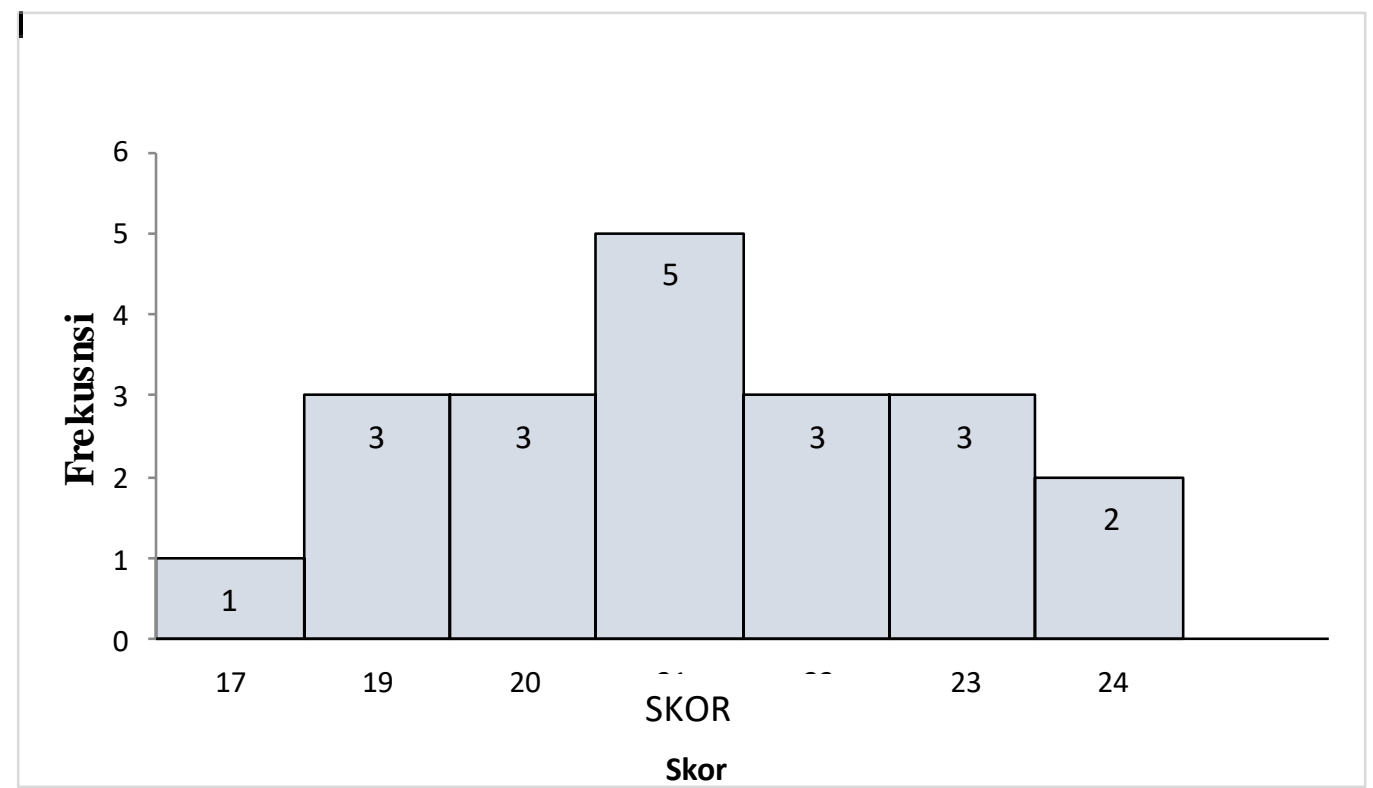

Gambar 1. Histogram Data Hasil Kelompok Eksperimen

Berdasarkan Grafik polygon data hasil belajar IPS kelompok eksperimen pada gambar 4.1, dapat diketahui bahwa mean lebih besar dari median, dan median sama besar dengan modus $\mathrm{M}>\mathrm{Me}=\mathrm{Mo}(27,173>27=27)$. Jika dilihat gambar grafik polygon tersebut termasuk kurva normal. Untuk mengetahui kualitas variabel hasil belajar IPS pada kelompok eksperimen, data skor ratarata hasil belajar IPS siswa dikonversikan menggunakan kriteria rata-rata ideal ( i) dan standar deviasi ideal (SDi). Skor rata-rata hasil belajar IPS kelompok eksperimen sebesar 27,173 (terletak antara $22,5 \leq \leq 30$ ) berada pada kategori sangat tinggi.

Sedangkan data hasil belajar siswa kelompok kontrol dapat disajikan ke dalam bentuk Histogram seperti Gambar 2. 


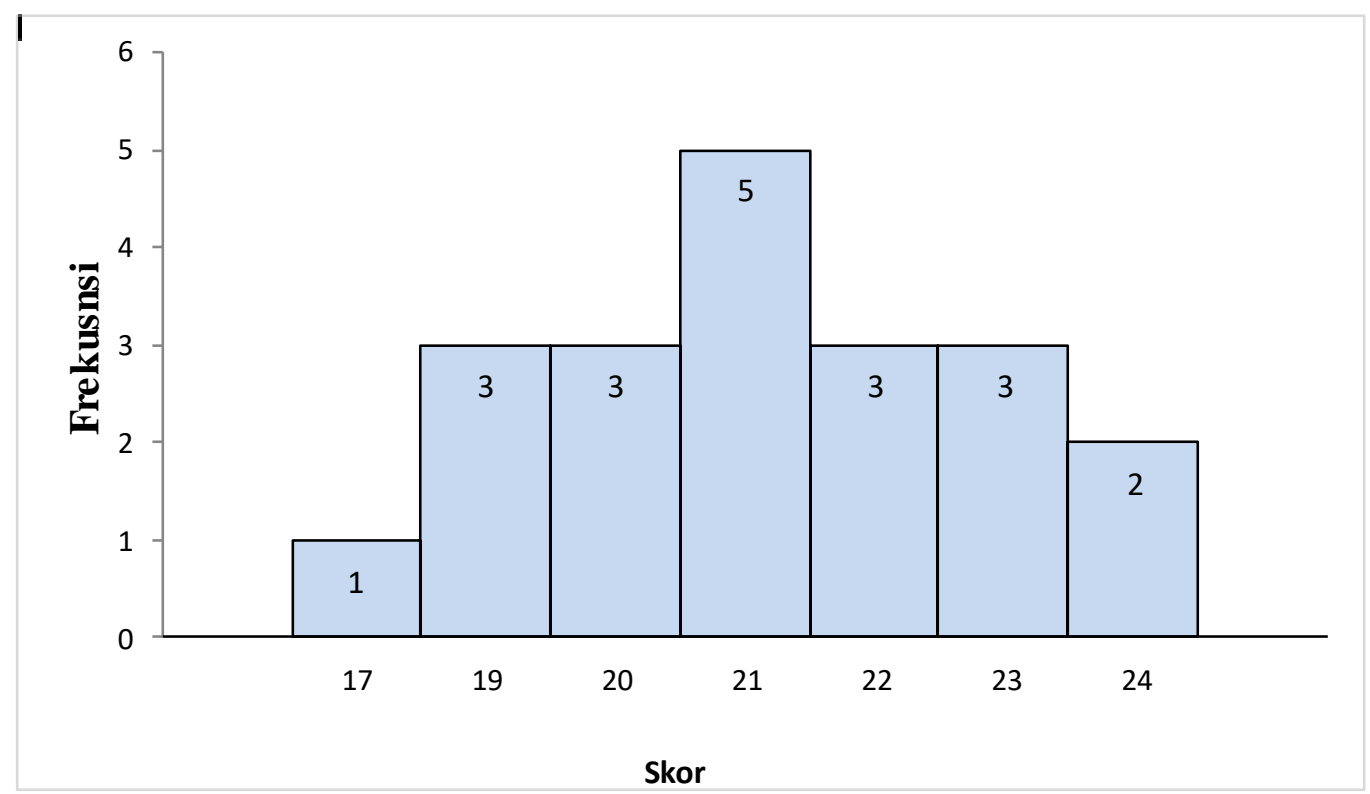

Gambar 2. Histogram Data Hasil Belajar Kelompok Kontrol

Berdasarkan Grafik polygon data hasil belajar IPS kelompok kontrol pada gambar 4.2, dapat diketahui bahwa mean lebih besar dari median, dan median sama besar dengan modus $\mathrm{M}>\mathrm{Me}=\mathrm{Mo}(21,1>21=21)$. Jika dilihat gambar grafik polygon tersebut termasuk kurva normal. Untuk mengetahui kualitas variabel hasil belajar IPS pada kelompok kontrol, data skor rata-rata hasil belajar IPS siswa dikonversikan menggunakan kriteria rata-rata ideal (Xi) dan standar deviasi ideal (SDi). Skor rata-rata hasil belajar IPS kelompok kontrol sebesar 21,1 (terletak antara 17,5<X$\leq 22,5$ ) berada pada kategori tinggi.

Kemudian dilakukan uji hipotesis untuk mengetahui pangaruh dari model pembelajaran yang diterapkan. Namun sebelum dilakukan uji hipotesis terlebih dahulu dilakukan uji prasyarat analisis data yaitu normalitas dan homogenitas. Rangkuman hasil uji normalitas disajikan pada Tabel 05 sebagai berikut.

Tabel 05 Uji Normalitas

\begin{tabular}{llrr}
\hline \multicolumn{5}{c}{ One-Sample Kolmogorov-Smirnov Test } \\
\hline & & $\begin{array}{c}\text { Posttest_Kontr } \\
\text { ol }\end{array}$ & $\begin{array}{r}\text { Posttest_Eksperim } \\
\text { en }\end{array}$ \\
\hline $\mathrm{N}$ & Mean & 20 & 23 \\
\hline Normal Parameters ${ }^{\mathrm{a}, \mathrm{b}}$ & Std. & 21,10 & 27,17 \\
& Deviation & 1,832 & 1,466 \\
\hline Most Extreme Differences & Absolute &, 128 &, 156 \\
\cline { 2 - 4 } & Positive &, 122 &, 156 \\
\cline { 2 - 4 } & Negative &,- 128 &,- 148 \\
\hline Test Statistic & &, 128 &, 156 \\
\hline Asymp. Sig. (2-tailed) & & &, $154^{c}$ \\
\hline a. Test distribution is Normal. & & & \\
\hline b. Calculated from data. & & &
\end{tabular}


Berdasarkan hasil perhitungan post-test kelompok eksperimen dan kontrol dengan menggunakan SPSS 22.0 for windows, dari output analisis menunjukkan nilai Kolmogrov Smirnov (a) post-test kelompok kontrol adalah 0,200 lebih besar dari nilai signifikan $>0,05$, maka data hasil post-test kelompok kontrol berdistribusi normal. Dan dari output analisis menunjukkan nilai Kolmogrov Smirnov (a) post-test kelompok eksperimenadalah 0,154 lebih besar dari nilai signifikan > 0,05, maka data hasil post-test kelompok eksperimen berdistribusi normal. Oleh karena itu nilai probabilitas kedua nilai signifikan $>0,05$, maka data hasil post-test kelompok eksperimen dan kontrol berdistribusi normal. Selanjutnya rangkuman hasil uji homogenitas disajikan pada Tabel 06 sebagai berikut.

Tabel 06 Uji Homogenitas

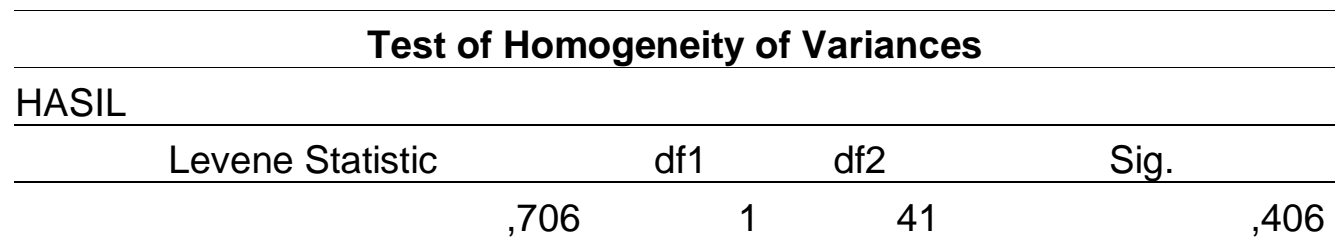

Hasil analisis menunjukan bahwa angka signifikan yang dihasilkan lebih besar dari 0,05. Dengan demikian dapat disimpulkan bahwa data hasil belajar pada mata pelajaran IPS pada kelompok eksperimen dan kelompok kontrol mempunyai varian yang homogen. Oleh karena sudah dipenuhi semua uji prasyarat analisis yaitu uji normalitas sebaran data dan uji homogenitas varians sehingga uji hipotesis dapat dilaksanakan menggunakan Uji-t. Rangkuman hasil hipotesis disajikan pada Tabel 07 sebagai berikut.

\section{Tabel 07 Uji-t}

\section{Independent Samples Test}

\begin{tabular}{|c|c|c|c|c|c|c|c|c|c|c|}
\hline & & $\begin{array}{r}\text { Leve } \\
\text { Tes } \\
\text { Equa } \\
\text { Varia }\end{array}$ & $\begin{array}{l}\text { ne's } \\
\text { for } \\
\text { ity of } \\
\text { nces }\end{array}$ & & & $t$-test $f$ & for Equality & of Means & & \\
\hline & & & & & & & & & $\begin{array}{r}95 \% \text { Co } \\
\text { Interva } \\
\text { Diffe }\end{array}$ & $\begin{array}{l}\text { fidence } \\
\text { of the } \\
\text { ence }\end{array}$ \\
\hline & & $F$ & Sig. & $\mathrm{T}$ & $d f$ & tailed) & Difference & Difference & Lower & Upper \\
\hline $\begin{array}{l}\text { Hasil_Bel } \\
\text { ajar_IPS }\end{array}$ & $\begin{array}{l}\text { Equal } \\
\text { variances } \\
\text { assumed }\end{array}$ & ,706 & ,406 & $-12,068$ & 41 & ,000 & $-6,074$ & ,503 & $-7,090$ & $-5,057$ \\
\hline & $\begin{array}{l}\text { Equal } \\
\text { variances } \\
\text { not } \\
\text { assumed }\end{array}$ & & & $-11,880$ & 36,324 & ,000 & $-6,074$ &, 511 & $-7,110$ & $-5,037$ \\
\hline
\end{tabular}

Berdasarkan pengujian yang telah dilakukan menggunakan bantuan program SPSS-22.0 for windowsbesar signifikan (2-tailed) sebesar 0,000. Hasil ini menunjukan besar signifikansi lebih kecil dari 0,05 $(p<0,05)$, sehingga hasilnya adalah signifikan (ada pengaruh yang signifikan), yang menunjukkan adanya perbedaan yang signifikan antara kelas eksperimen dan kelas kontrol, maka $\mathrm{H}_{1}$ diterima dan $\mathrm{H}_{0}$ ditolak. Dapat disimpulkan bahwa terdapat pengaruh yang signifikan model 
pembelajaran Role Playing Berorientasi Tri Kaya Parisudha Untuk Meningkatkan Hasil Belajar IPS Siswa Kelas IV di Gugus VII Kecamatan Sukasada Kabupaten Buleleng Tahun Pelajaran 2018/2019.

Ketika dalam proses pembelajaran ada beberapa hal yang diamati, ketika siswa diberikan model pembelajaran Role Playing Berorientasi Tri kaya Parisudha, yaitu dalam penggunaan model tersebut siswa terlihat lebih aktif memainkan peran yang diberikan. Ini dikarenakan dengan bermain peran akan memberikan unsur senang kepada siswa, sehingga suatu kerja sama akan terlihat dan dirasakan oleh siswa. Pembelajaran dilakukan dengan cara seolah-olah siswa berada dalam situasi untuk memperoleh suatu pemahaman tentang suatu konsep, hal tersebut jika diterapkan maka setiap siswa dapat melakukan improvisasi bersama teman-temannya berdasarkan skenario yang telah dibuat.

Temuan ini dipertegas oleh Fogg (dalam Huda, 2014: 208), "role playing atau bermain peran adalah sejenis permain gerak yang di dalamnya ada tujuan, aturan, dan edutainment'. Kegiatan role playing menjadikan suatu pembelajaran yang menyenangkan, karena didesain dengan memadukan antarmuatan pendidikan dan hiburan secara harmonis. Pendapat tersebut sejalan dengan Khaerani (2010: 15) yang menyatakan bahwa: role playing membuat siswa menjadi lebih tertarik dan terlibat tidak hanya belajar mengenai suatu konsep, tetapi juga mengintegrasikan pengetahuan terhadap perilaku melalui pengklasifikasian masalah-masalah, mengeksplorasi alternatif-alternatif, dan mencari solusi-solusi yang kreatif.

Berkaitan dengan model pembelajaran Role Playing, ada suatu konsep yang mengakar pada kehidupan sosial masyarakat Bali, yang dikenal dengan nama konsep Tri Kaya Parisudha. "Tri kaya Parisudha diartikan sebagai tiga dasar perbuatan manusia yang harus disucikan, yaitu manacika, wacika, dan kayika, manacika artinya berpikir yang baik, wacika artinya berkata yang baik, dan kayika artinya berbuat yang baik" Parisadha (dalam Astawan, 2018). Sukadi, dkk. (dalam Astawan, 2018) menjelaskan lebih jelas pengertian Tri Kaya Parisudha, yaitu manacika diartikan sebagai kemampuan berpikir yang baik, benar, dan bijaksana, wacika diartikan sebagai kemampuan berkata-kata yang jujur, benar, objektif, menyejukkan dan kayika diartikan sebagai kemampuan berprilaku atau berbuat yang baik dan benar serta selalu membahagiakan orang lain. Tri Kaya Parisudha merupakan suatu ajaran yang menjadi tuntunan bagi umat hindu di Bali yaitu tuntunan dalam berpikir, berkata, dan berbuat. Menyatunya aspek berpikir, berkata, dan berbuat merupakan kesatuan yang utuh dalam berperilaku atau berbuat dalam bermasyarakat. Tri Kaya Parisudha merupakan bagian dari etika (susila) agama hindu. Tri berarti tiga, Kaya artinya perbuatan atau gerak, Parisudha artinya suci atau baik dan benar. Dengan demikian, Tri Kaya Parisudha artinya tiga perbuatan yang harus disucikan. Tri Kaya Parisudha mempunyai tiga bagian yaitu: Manacika Parisudha (pikiran yang benar), Wacika Parisudha (perkataan yang benar), Kayika Parisudha (perbuatan atau laksana yang benar).

Pembelajaran dikelas dapat dimulai dengan fase satu (fase kayika) melalui pengamatan langsung. Selama melakukan pengamatan, anak-anak dilatih untuk jujur dan objektif mencatat data, berprilaku tertib dan sopan selama kegiatan pembelajaran, serta bertindak sesuai aturan yang disepakati. Setelah dilakukan pengamatan dilanjutkan fase kedua (fase wacika) dengan mengomunikasikan hasil pengamatan tersebut, pada fase ini anak-anak dilatih untuk menyampaikan hasil pengamatan dengan santun, bertanya dan menanggapi dengan kata-kata yang baik, serta menghargai perbedaan pendapat. Fase ketiga, (fase manacika), melakukan analisis dan refleksi terhadap hasil pengamatan dan diskusi tahapan sebelumnya. Pada fase ini anak dilatih untuk berpikir kritis dan dengan menganalisis hasil pengamatan dan diskusi sebelumnya, anak diajak untuk berpikir optimis bahwa mereka telah mampu mengikuti pembelajaran dan berpikir positif akan kemampuan dirinya. Dengan demikian, ada hubungan antara model pembelajaran Role playing dengan konsep Tri Kaya Parisudha.

Model pembelajaran Role Playing Berorientasi Tri Kaya Parisudha dapat meningkatkan hasil belajar siswa. Penelitian ini dipertegas oleh penelitian yang dilakukan oleh, Firman Wahyudin pada tahun 2014 hasil penelitian yang dilakukan menyatakan bahwa penggunaan model pembelajaran Role Playing memberikan pengaruh yang cukup besar terhadap tingginya hasil belajar kelas IV SDN 01 Kecamatan Selakau. Hal itu dapat dilihat dari rata-rata skor hasil belajar pendidikan kewarganegaraan siswa yang dibelajarkan dengan model pembelajaran Role Playing 
lebih besar dari nilai rata-rata siswa yang dibelajarkan dengan model pembelajaran konvensional yaitu rata-rata 77,25 dan 67,40 .

\section{Simpulan}

Berdasarkan hasil penelitian dan pembahasan, dapat disimpulkan bahwa terdapat pengaruh yang signifikan hasil belajar IPS siswa yang dibelajarkan melalui model pembelajaran Role Playing Berorientasi Tri Kaya Parisudha dan siswa yang tidak dibelajarkan melalui model pembelajaran Role Playing Berorientasi Tri Kaya Parisudha pada kelas IV Sekolah Dasar di Gugus VII Kecamatan Sukasada Kabupaten Buleleng Tahun Pelajaran 2018/2019. Hal ini dapat dilihat dari hasil uji-t diperoleh nilai $t_{\text {hitung }}=12,387>$ nilai $t_{\text {tabel }}=2,019$. Adanya pengaruh yang signifikan model pembelajaran Role Playing Berorientasi Tri Kaya Parisudha berpengaruh positif terhadap hasil belajar IPS siswa kelas IV Sekolah Dasar di Gugus VII Kecamatan Sukasada Kabupaten Buleleng Tahun Pelajaran 2018/2019.

Berdasarkan simpulan penelitian yang telah dipaparkan, maka dapat diajukan beberapa saran guna peningkatan kualitas pembelajaran IPS sebagai berikut Pertama, kepada guru, disarankan untuk mengembangakan pembelajaran IPS dengan menggunakan model pembelajaran dan media yang inovatif. Salah satu model pembelajaran yaitu model pembelajaran Role Playing Berorientasi Tri Kaya Parisudha sehingga dapat mengoptimalkan hasil belajar IPS siswa. Kedua, kepada kepala sekolah, agar selalu mendukung dan memberikan pelatihan dalam penggunaan serta pengembangan model pembelajaran Role Playing Berorientasi Tri Kaya Parisudha. Ketiga, kepada peneliti lain, untuk meneruskan penelitian ini agar mampu menjangkau masalah-masalah lain berkaitan dengan masalah penelitian yang belum ditemukan dalam penelitian ini, sehingga menjadi penelitian yang lebih sempurna dari penelitian ini.

\section{Daftar Rujukan}

Astawan, I Gede (dkk). 2018. Teori \& Aplikasi Model Pembelajaran Tri Kaya Parisudha Di Sekolah Dasar. Singaraja: Undiksha Press

Hanafy, Muhamad Sain. 2014. Konsep Belajar dan Pembelajaran.Fakultas Tarbiyah dan Keguruan UIN Alauddin Makasar.

journal.uinalauddin.ac.id/index.php/lentera_pendidikan/article/view/516

Huda, M. 2014. Model-Model Pengajaran dan Pembelajaran Isu-isu Metodis dan Paradigmatis. Yogyakarta: Pustaka Pelajar.

Isrok'atun. (dkk). 2018. Model-Model Pembelajaran Matematika. Jakarta: PT Bumi Aksara

Kurniasih, I Sani. B. Ragam Pengembangan Model Pembelajaran Untuk Peningkatan Profesionalitas Guru. Singaraja: Kata Pena.

Rusman. (2015). Pembelajaran Tematik Terpadu Teori Praktik dan Penilaian. Jakarta: Rajawali Pres.

Sugiyono. 2012. Metode Penelitian Pendidikan. Bandung: Alfabeta.

Susanto, Ahmad. 2013. Teori Belajar dan Pembelajaran di Sekolah Dasar. Jakarta: Kencana Prenada Media Group.

Trianto, 2007. Model-Model Pembelajaran Inovatif Berorientasi Kontruktivistik. Jakarta: Prestasi Pustaka.

Wahyudin, Firman. (dkk). 2014. Pengaruh Metode Role Playing Terhadap Hasil Belajar Peserta Didik Dalam Pembelajaran PKN Kelas IV. Artikel Penelitian (tidak diterbitkan). Jurusan PGSD, FKIP Universitas Tanjungpura. Pontianak. 
PIPS, Vol. 2 No. 2, Bulan Oktober Tahun 2018

ISSN:2614-8366

Yuliani. 2017. "Meningkatkan Hasil Belajar Siswa Pada Pembelajaran PKn Melalui Model Pembelajaran Role Playing di Kelas IV SD Inpres Cendanapura". Tadulako, Volume 5, Nomor 